\title{
Enhancement of Poly-Crystal PV Panels Performance by Air-to-Air Heat Exchanger Cooling System
}

\author{
KHALEEL ABUSHGAIR \\ Mechanical Engineering Department, Faculty of Engineering Technology \\ Al-Balqa Applied University, Amman, Marka,11134, JORDAN
}

\begin{abstract}
The temperature of silicon Poly-Crystal photovoltaic (PV) solar panels has a significant impact on their efficiency emphasizing the necessity of cooling approach to be used. The current study looked at the impact of adopting a unique forced convictive air-to-air heat exchanger as a cooling approach to boost the efficiency of PV solar panels, as efficiency of silicon Poly-Crystal PV solar panels would decrease as its temperature increased. The research was carried out experimentally with both an uncooled and cooled PV system. A unique cooling system for PV panels was designed and experimentally investigated in Amman, Jordan included a heat exchanger connected to a blower that drove ambient air over the back-panel surface and a chimney to draw the cooled air outside. This cooling system would improve the PV panel's efficiency. It was found that by directing cooled air over the bottom surface of the PV module at an ideal rate of $0.01020 \mathrm{~m}^{3} / \mathrm{s}$, the temperature of the PV module could be reduced from an average of $40{ }^{\circ} \mathrm{C}$ (without cooling) to $34{ }^{\circ} \mathrm{C}$. As a result, the efficiency and output power of PV modules increased by roughly $2 \%$ and $12.8 \%$, respectively.
\end{abstract}

Keywords: Poly-Crystal PV Panels, PV Performance, Cooling, Forced convection, Heat exchanger.

Received: January 15, 2021. Revised: July 28, 2021. Accepted: August 1, 2021. Published: August 8, 2021.

\section{Introduction}

Electrical power via photovoltaic (PV) solar panels over the last decade was generated in more than 100 countries. Unfortunately, it didn't reach the 5terawatt level in the whole world. Therefore, electricity produced via PV panels is a tiny fraction of the total global electricity generation. Global solar power capacity rose from $25 \mathrm{GW}$ in early 2010 to approximately $618 \mathrm{GW}$ in 2019 which was reflected on the increase in total investments in the solar energy sector especially in the Middle East and North Africa countries [1].The first conventional PV panel was produced around 1950 [2] and its purpose was to provide power to satellites orbiting around the earth. Later, improvements on the PV panels kept rolling the costs down and the performance was enhanced where the usage was mainly limited to low power needs (charging batteries, signal telecommunication equipment's, remote terrestrial applications, etc.). The main problem associated with using PV panels for high power demanding is the high cost and the solar radiation received by PV thermal systems but not converted into electrical energy causes a thermal issue that has a major impact on the PV cells' durability and performance [3-4]. As a result, researchers are focusing on finding ways to reduce cost and increase the power produced.

Despite the fact that the PV cell generates energy, it was observed that the efficiency decreases as the temperature of the PV cell rise . Temperature is a key element that stops PV solar panels from producing energy and causes them to lose efficiency [5, 6]. When a PV module is exposed to sunlight, the amount of heat energy converted to usable energy is around $31 \%$ with a higher proportion conversion to heat energy that causes the temperature of the module to increase, resulting in a reduction in the generated electricity [7]. According to research on the effects of increasing PV cells' temperatures on its efficiency it was reported that output voltage of a solar cell declined by $4 \%-5 \%$ for every $1{ }^{\circ} \mathrm{C}$ increase in temperature. Higher cell temperatures not only reduce 
power output, but they also increase cell deterioration, resulting in early failure [8-9]. As a result, cooling the PV cells was required to improve their efficiency[10] . To improve PV systems overall efficiency more emphasis should be given on operational issues and PV cooling system design which could be a heat exchanger attached to the bottom surface of the PV module and could collect heat from air or water [11].

Because of their low construction costs (material usage) and operating costs, PV-air systems have been nominated for use in a variety of intriguing applications [12]. Even though air-based systems have limited effectiveness due to low air density and heat capacity, such technology is appealing in hot climates with limited water supplies [13]. Active cooling methods which use fans to push and accelerate the flow rate of air to the PV module are one of the many air cooling technologies that strive to increase the efficiency of PV systems and extend their lifespan. [14, 15]. The efficiency of an active airbased cooling system can be enhanced (5 \% -10\%) [16]. This means that active cooling approaches provided greater power as well as more available energy [17]. Furthermore, a study on an air-based cooled PV system using a blower fan and a specifically constructed duct system was suggested for cooling a PV panel by induced airflow on the PV panel's backside surface. The duct system increased convective heat transport, and it was designed to maximize the PV panels' power output. With a $30^{\circ} \mathrm{C}$ drop in PV panel operating temperature the efficiency gained ranged from $12 \%$ to $14 \%$ on average [18].

Natural convection along the PV panels' bottom surface have been studied by Moshfegh and Sandberg. They used a $7 \mathrm{~m}$ module length with an air gap of $0.23 \mathrm{~m}$ in their studies to investigate heat exchange through radiation. The emissivity of the boundary surfaces and various input heat fluxes were factored in. They also reported that the surface beneath $\theta$ the PV panel had absorbed around $30 \%$ of the heat produced by the solar panel while the residue being lost by convection [15]. Another investigation was done by Salaudeen, 2019 to assess the performance of a thermal energy storage system using paraffin wax as the storage medium and air as the heat transmission fluid. Because of its availability and durability, Salaudeen discovered that air was the optimum heat transfer fluid [19]. Teo et al., conducted a new study to improve the electrical efficiency of aircooled PV modules. The work investigated the impacts of active and passive cooling using both analytical and simulation analyses. One of the results of their study was a newly constructed manifold, which enhanced airflow uniformity, therefore enhanced temperature distribution uniformity. Because of the minimal temperature gradient, thermal stress was reduced, extending the system's lifetime [20].

In this paper, an experimental assessment of a PV system with a cooling design that would enhance the system efficiency was performed by employing a heat exchanger based on forced convection. The main goal was to develop and test a cooling strategy that could achieve a uniform temperature profile while maintaining the cell temperature to a minimal level. The ambient data needed for the analysis was collected on a specific April day. Based on radiation, thermal, and electrical factors, a detailed analysis of the PV system was conducted. The entire performance of the cooled and uncooled PV was then evaluated using the PV system model. For the thermal and electrical characteristics, the experimental results were compared to the model.

\section{Experimental Procedure}

\subsection{Solar Radiations in Jordan}

Solar radian measurements were taken during the spring season in Jordan that includes the month of April. Jordan is well known for its high-quality solar radiation and clear sky around the year. In Jordan, the amount of solar radiation is high compared with other countries because the angle of fall is close to the vertical angle as shown in Figure 1. Figure 2 showed the hourly solar radiation for measurement day 1 . The maximum solar radiation occurred at 11:00 am with around $820 \mathrm{~W} / \mathrm{m}^{2}$ of solar radiation. This value was considered an excellent value for such a day in April since the weather was partially hot with clear sky. Therefore, the maximum value of the solar radiation was taken as an input for the 
design of the adopted heat exchanger which then was used to estimate the available heat power to be dissipated from the PV solar panel.

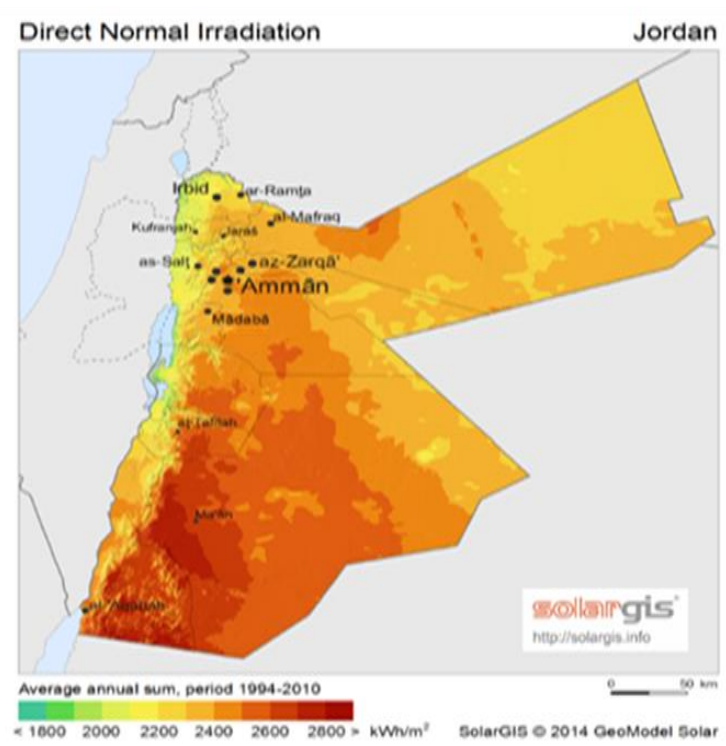

Figure 1. Solar Radiation Distribution in Jordan [21].

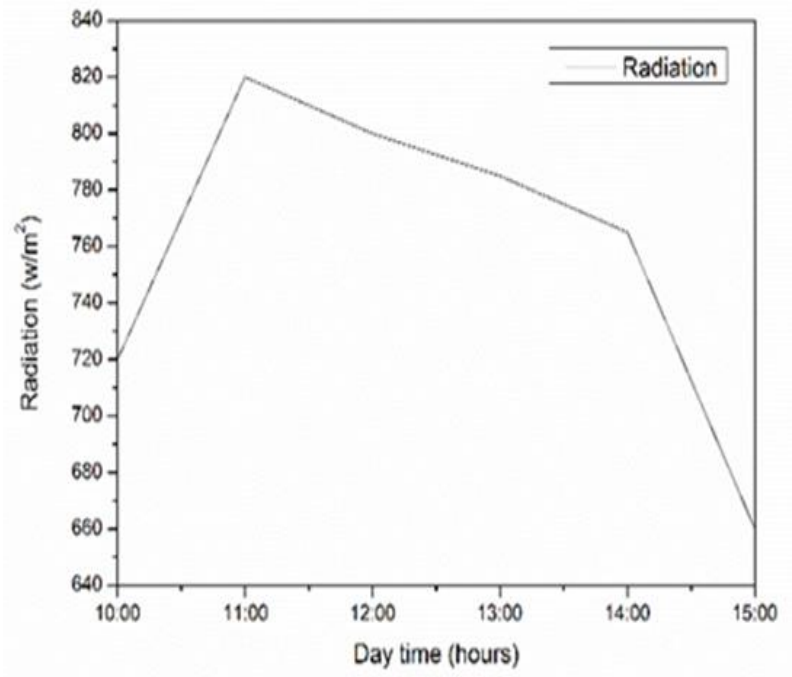

Figure 2. Solar Radiation during April Day 1 Measurement.

\section{Heat Exchanger Design}

Figure 3 showed the suggested air-to-air heat exchanger with simple design.

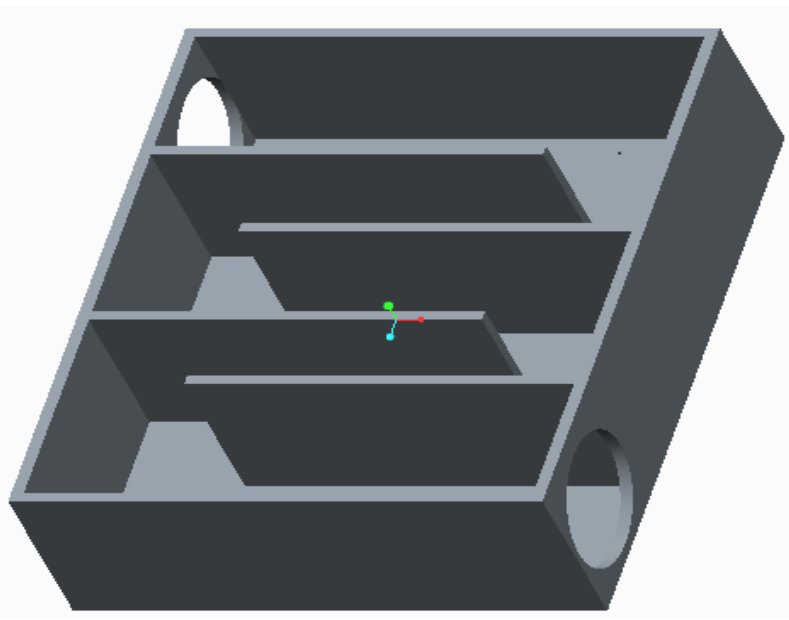

Figure 3. A Sketch for Designed Air-to-air Forced Heat Exchanger.

The PV cooling system and its main designed airto-air forced heat exchangers are shown in Figure 4.

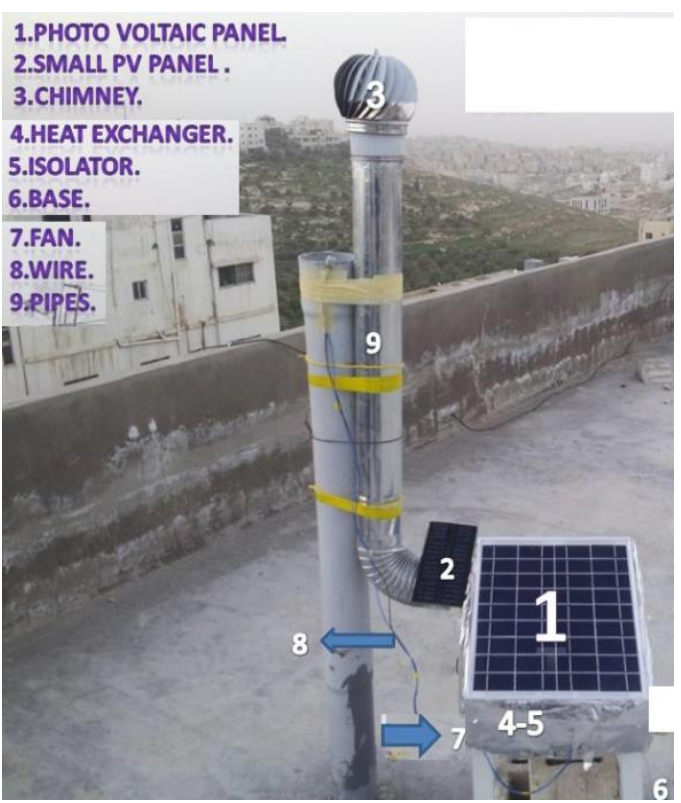

Figure 4. The Proposed PV Cooling System.

\subsection{Heat Exchanger Design}

Equation 1 was used to calculate the amount of heat that may be rejected during cooling of the system. From measurement day 1 the maximum radiation of $820 \mathrm{~W} / \mathrm{m}^{2}$ was found.

$\mathbf{Q}_{\text {absorbed }}=\mathbf{Q}_{\text {radiation }} *$ emissivity low iron glass 1

Used Glass emissivity was 0.9 , the energy absorbed by the panel was around $1.9 \mathrm{~W}$ and energy absorbed 
by panel that will be converted to electrical and thermal energy $Q_{\text {thermal }}$ was calculated to be $92 \mathrm{~W}$. Convection heat transfer coefficient was given in Equation 2.

$\mathbf{Q}=\mathbf{H} * \mathbf{A} *\left(\mathbf{T}_{\mathbf{p v}}-\mathbf{T}_{\text {air }}\right)$

\section{2}

The required area of the heat exchanger with estimated efficiency of around $94 \%$ was estimated to be equal to $\left(\mathrm{A}=0.155 \mathrm{~m}^{2}\right)$.

The heat rejected area by forced convection via the proposed heat exchanger was calculated based on Equation 3.

$V_{D}=\mathbf{( 3 . 1 4 / 4 )} *\left(D^{2}-d^{2}\right)$

Where $\mathrm{D}$ was the outer diameter in meter for the blower fan $(9 \mathrm{~cm})$ and $\mathrm{d}$ was the inner diameter in meter for blower fan $(3 \mathrm{~cm})$, which resulted in a value of $\left(V_{D}=5.6548^{*} 10^{-3} \mathrm{~m}^{2}\right)$. Assuming the fan speed was 110 RPM, the resulted volume flow rate of air was equal to $\mathrm{Q}\left(=0.01020 \mathrm{~m}^{3} / \mathrm{s}\right)$ based on Equation 4 .

\section{Q} $=\mathbf{V}_{\mathbf{D}}$

*speed

160

4

Therefore, the generated power from solar panels could be calculated based on Equation 5 .

$$
\mathbf{P}=\mathbf{V o c} * \mathbf{I s c} * \mathbf{F F}
$$

Where Voc was the measured output voltage in volte and Isc was the measured output current in Amber.

\section{Results and Discussion}

\subsection{Experimental Measurement 1}

The weather measurement day was a normal clearsky spring day in April

Figure 5 showed the measured air and solar panel temperature without cooling in Amman-Jordan for the period from 10:00 a.m. to 15:00 p.m.

It was clear that the solar panel temperature being higher than the ambient temperature of air during the whole measured day time with difference around $4^{\circ} \mathrm{C}$.

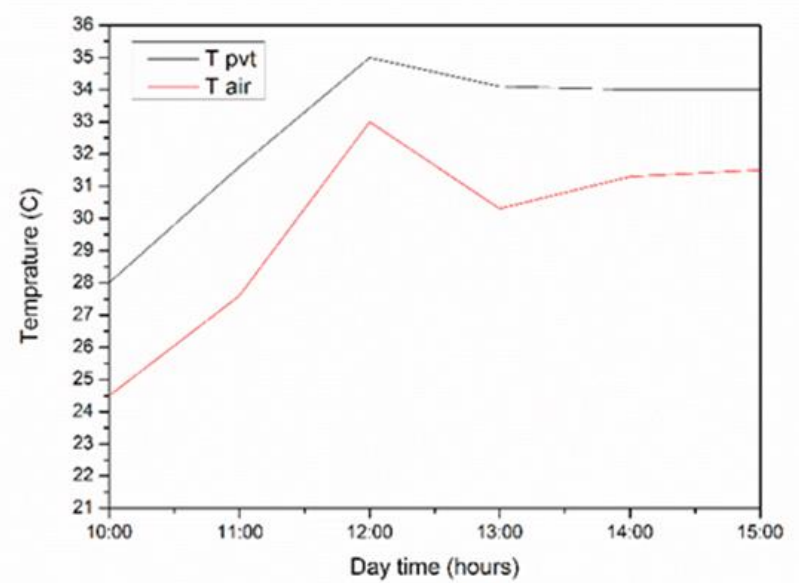

Figure 5. Measured Air and PV Temperature without Designed Cooling System.

Figure 6 showed the measured temperature of PV with and without cooling system. Notable difference in temperature values could be seen which clarified the effect of the designed cooling system in reducing the temperature of the PV panel. As the designed cooling system was able to reduce the temperature of the solar panel, the output voltage also was increased as seen in Figure 7 with voltage difference around 2 Volts.

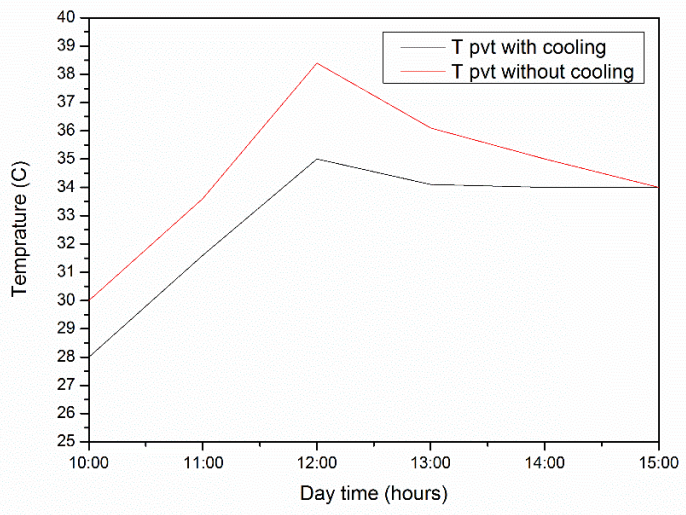

Figure 6. Measured PV Temperature with and without Designed Cooling System. 


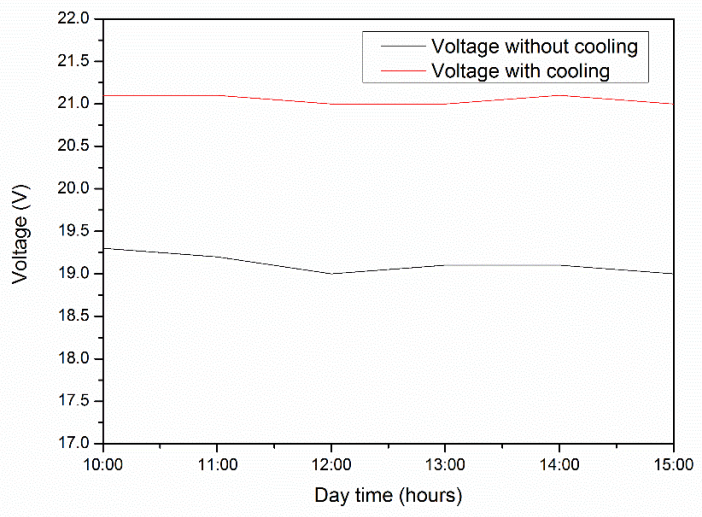

Figure 7. Measured Output Voltage for PV Panels with and without Designed Cooling System.

\subsection{Experimental Measurement 2}

During this day the weather was hot with a clear sky and. Figure 8 showed the radiation in the period from 8:00 a.m. to $15: 00$ p.m. daytime, where maximum radiation was $860 \mathrm{~W} / \mathrm{m}^{2}$ around 11:30 a.m.

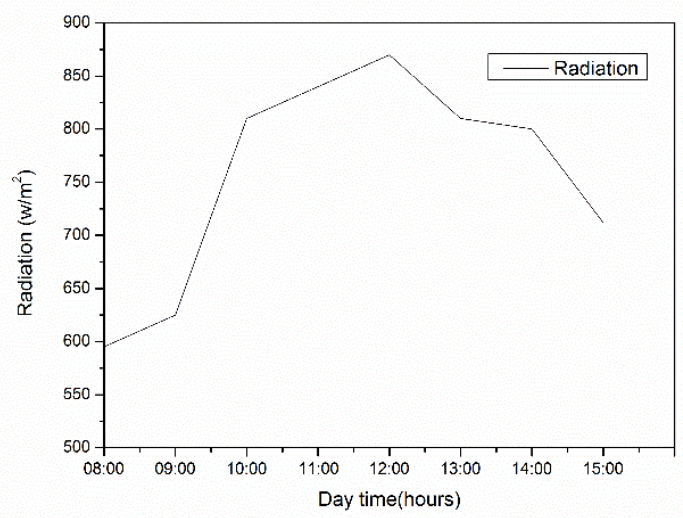

Figure 8. Solar Radiation During Experimental Measurement 2.

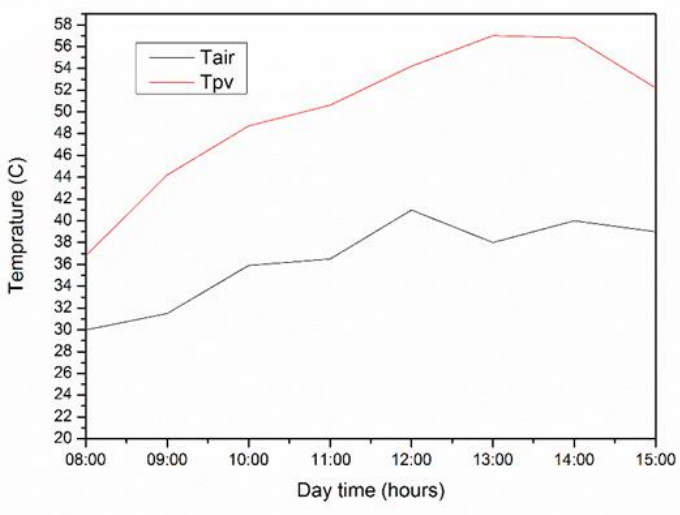

Figure 9. Measured Air and PV Temperature without Designed Cooling System.

From Figure 9 the PV temperature was around $57^{\circ} \mathrm{C}$, while ambient air temperature was around $40{ }^{\circ} \mathrm{C}$. Difference in temperature was seen in the measured period from 8:00 a.m. to 15:00 p.m. daytime. Adding the forced air-to-air heat exchanger cooling device was able to reduce temperature of PV panel even in hot weather as seen in Figure 10. With more than 10 degrees reduction a resulted measured output voltage of the cooled solar panel was higher than the uncooled one with around 2 volts difference as seen in figure 11.

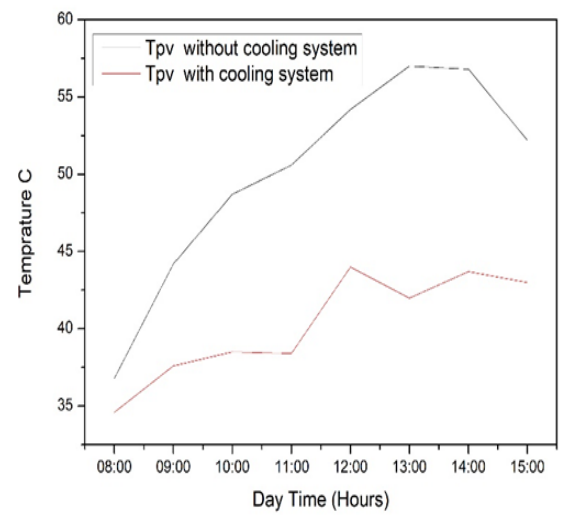


Figure 10. Measured PV Temperature with and without the Designed Cooling System

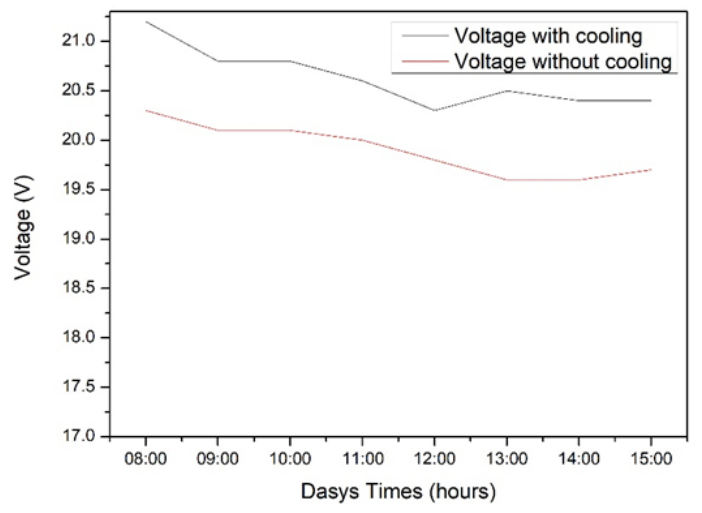

Figure 11. Measured Output Voltage for PV Panels with and without the Designed Cooling System.

The calculated efficiency of solar panels with and without cooling system were shown in Figure 12. The efficiency of panel without cooling at $39^{\circ} \mathrm{C}$ and radiation equal $875 \mathrm{w} / \mathrm{m}^{2}$ was $12.34 \%$, and with the cooling system at $34.7^{\circ} \mathrm{C}$ and radiation equal 875 $\mathrm{W} / \mathrm{m}^{2}$ was around $14.16 \%$. The increase in the efficiency was $1.82 \%$.

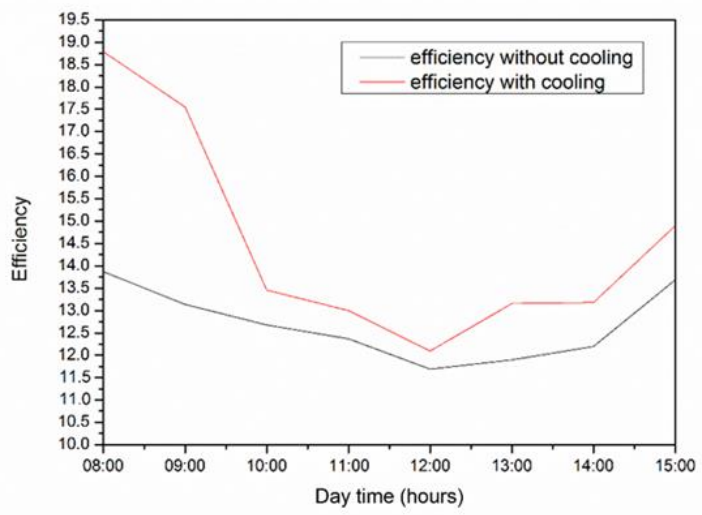

Figure 12. Measured Output Voltage for PV panels with and without the Designed Cooling System.

\section{Conclusion}

To increase the efficiency of cooling silicon PolyCrystal photovoltaic solar panels, an experimental and theoretical study was conducted to build a unique forced convicting cooling design of air-to-air heat exchanger. For local conditions in Amman, Jordan, the experiment was conducted to assess ambient air temperature, photovoltaic temperature, output voltage, and efficiency for silicon Poly-Crystal photovoltaic solar panels with and without cooling system. The cooling system was used to cool the photovoltaic panel's back surface and improve its performance at the same time. The results showed that by channeling cooled air over the bottom surface of a photovoltaic module at an ideal rate of 0.01020 $\mathrm{m}^{3} / \mathrm{s}$ it was possible to reduce the temperature of a photovoltaic module from an average of $40{ }^{\circ} \mathrm{C}$ (without cooling) to $34{ }^{\circ} \mathrm{C}$. Photovoltaic module efficiency and output power was improved by roughly $2 \%$ and $12.8 \%$, respectively at this optimal flow rate and due to the decline in photovoltaic module temperature.

\section{References}

[1]. Li, D., et al., Study on the cleaning and cooling of solar photovoltaic panels using compressed airflow. Solar Energy, 2021. 221: p. 433-444.

[2]. Kumar, A., P. Baredar, and U. Qureshi, Historical and recent development of photovoltaic thermal (PVT) technologies. Renewable and Sustainable Energy Reviews, 2015. 42: p. 1428-1436.

[3]. ZAITE, A., et al., Performance improvement of photovoltaic cells using night radiative cooling technology in a PV/T collector. Journal of Building Engineering, 2021: p. 102843.

[4]. Abushgair, K.; Al-Waked, R. Effects of Coating Materials as a Cleaning Agent on the Performance of Poly-Crystal PV Panels. Coatings 2021, 11, 544.

[5]. Hossain, M., et al., Thermal performance analysis of parallel serpentine flow based photovoltaic/thermal (PV/T) system under composite climate of Malaysia. Applied Thermal Engineering, 2019. 153: p. 861-871.

[6]. Tan, L., et al., Efficiency gains of photovoltaic system using latent heat thermal energy storage. Energy Procedia, 2017. 110: p. 83-88.

[7]. Sethiya, A., Cooling material for solar PV module to improve the generation efficiency. Materials Today: Proceedings, 2021. 
[8]. Bazzari Huda, H.; Abushgair Khaleel, N.; Hamdan Mohammad, A.; Alkhaldi Hashem, S. Cooling solar cells using $\mathrm{ZnO}$ nanoparticles as a down-shifter. Therm. Sci. 2020, 24, 809-814.

[9]. Atsu, D. and A. Dhaundiyal, Effect of ambient parameters on the temperature distribution of photovoltaic (PV) modules. Resources, 2019. 8(2): p. 107.

[10].Tonui, J. and Y. Tripanagnostopoulos, Performance improvement of $\mathrm{PV} / \mathrm{T}$ solar collectors with natural air flow operation. Solar energy, 2008. 82(1): p. 1-12.

[11].Nasrin, R., M. Hasanuzzaman, and N.A. Rahim, Effect of high irradiation and cooling on power, energy and performance of a PVT system. Renewable energy, 2018. 116: p. 552569.

[12].Tonui, J. and Y. Tripanagnostopoulos, Aircooled PV/T solar collectors with low cost performance improvements. Solar energy, 2007. 81(4): p. 498-511.

[13].Elminshawy, N.A., et al., Performance of PV panel coupled with geothermal air cooling system subjected to hot climatic. Applied Thermal Engineering, 2019. 148: p. 1-9.

[14].Naghavi, M., et al., Experimental and numerical assessments of underlying natural air movement on PV modules temperature. Solar Energy, 2021. 216: p. 610-622.

[15].Almuwailhi, A. and O. Zeitoun, Investigating the cooling of solar photovoltaic modules under the conditions of Riyadh. Journal of King Saud University-Engineering Sciences, 2021.

[16].Kiwan, S.M. and A.M. Khlefat, Thermal cooling of photovoltaic panels using porous material. Case Studies in Thermal Engineering, 2021. 24: p. 100837.

[17].Khordehgah, N., A. Żabnieńska-Góra, and H. Jouhara, Energy performance analysis of a $\mathrm{PV} / \mathrm{T}$ system coupled with domestic hot water system. ChemEngineering, 2020. 4(2): p. 22.

[18].Nižetić, S., E. Giama, and A. Papadopoulos, Comprehensive analysis and general economic-environmental evaluation of cooling techniques for photovoltaic panels, Part II: Active cooling techniques. Energy Conversion and Management, 2018. 155: p. 301-323.

[19].Salaudeen, S.A., Investigation on the performance and environmental impact of a latent heat thermal energy storage system. Journal of King Saud University-Engineering Sciences, 2019. 31(4): p. 368-374.

[20].Teo, H., P. Lee, and M. Hawlader, An active cooling system for photovoltaic modules. applied energy, 2012. 90(1): p. 309-315.

[21].Goussous, J., H. Siam, and H. Alzoubi, Prospects of green roof technology for energy and thermal benefits in buildings: Case of Jordan. Sustainable cities and Society, 2015. 14: p. 425-440.

\section{Creative Commons Attribution License 4.0 (Attribution 4.0 International, CC BY 4.0)}

This article is published under the terms of the Creative Commons Attribution License 4.0

https://creativecommons.org/licenses/by/4.0/deed.en US 